\title{
Varieties of simulation experience
}

\author{
Neil Tuttle ${ }^{1 *}$ and Gary Grant ${ }^{2}$
}

In an era of evidence-based medicine, case reports are still considered to pave the way for the higher levels of medical research [1] resulting in a number of journals including or being dedicated to publishing case reports. The era of evidence-based education began in the same decade as evidence-based medicine [2], and its application to simulation in healthcare education was advanced by reporting guidelines published in this journal [3]. In contrast to the large number of outlets for case studies in medical journals, there are few outlets for analogous studies in simulation or healthcare education. The Innovation article type in Advances in Simulation is an exception, and the articles in this supplement describes what are essentially a series of case studies on the use of simulation in allied health education.

The title Varieties of Simulation Experience alludes to the seminal 1917 work Varieties of Religious Experience by William James [4] in which he states that "a large acquaintance with particulars often makes us wiser than the possession of abstract formulas, however deep." Simulation in healthcare is a broad church [5], and the articles in this issue take James' advice by putting an emphasis on the particulars and the experiences with less focus on abstract formulations.

The issue includes a series of stories illustrating some of what developed from the intense activity in simulation that occurred between 2012 and the present in Australia. During this time, the Australian Government through the now disestablished Health Workforce Australia provided over AU $\$ 100$ million for a range of projects that used simulation to support health professional development. The articles in this supplement represent a small sample of projects that were either directly funded through this initiative or developed from funded projects. Importantly, each of these projects is not requiring ongoing external funding.

The articles are structured as scholarly manuscripts, each including a component of evaluation and each telling a story-or at least part of a story since none yet

\footnotetext{
* Correspondence: n.tuttle@griffith.edu.au

'School of Allied Health Sciences, Griffith University, Gold Coast Campus,

Gold Coast, Queensland 4222, Australia

Full list of author information is available at the end of the article
}

have an ending. Individually and collectively, it is hoped that the stories acquaint the reader with some particulars of simulation experiences, not presuming to make the reader wiser or provide a template, but rather to provide stimuli for their own creativity. Although we believe there is an inherent value in each project, the primary aim in publishing these articles is the potential utility for others in developing their own simulation stories.

The projects have some similarities in that all are patient-centered involving live simulated patients and all involve entry level students and at least one allied health profession. In some ways, the projects are also characterised by their diversity. Ten disciplines are represented, some of which have limited the presence in simulation literature-such as exercise physiology [6-8], nutrition and dietetics [8], aboriginal health liaison, and allied health assistants [6]. Interprofessional learning was addressed by live interactions between combinations of disciplines in some studies $[6,8]$ and through targeted simulated interactions in others $[9,10]$. Innovative uses of technology through video-assisted debriefing [6], simulations via videoconferencing $[8,11]$, and the integration of an online adaptive learning platform to augment live simulation experiences [10]. While the technological innovations were promising, in each instance, the technology also presented significant challenges.

The duration of the experiences ranged from one $[6,8,11]$ to five half-days $[10]$. The varied aims included discovering the needs of a range of stakeholders [10], preparation for specific aspects [7], settings $[6,8,10]$ or areas of practice $[8,10,11]$, and general or interprofessional communication skills $[6,8]$. Planning and scenario development were the focus of one study [9], and another provided in-depth qualitative exploration of the experiences of facilitators and students [6].

A similar diversity is present in the approaches to evaluation. Most studies included mixed-methods, but the evaluation described in one was purely qualitative [6] and another purely quantitative [10]. Across the studies, all four of Kirkpatrick's four levels of evaluation of learning. Level 1 , reaction was considered in four 
studies [6-8, 11]; level 2, learning in four [6-8, 11]; level 3 , behavior in one; and level 4, results in one [10].

In summary, even with the limited sample of activities described in this supplement, there is a diversity of (1) disciplines, (2) types of interprofessional learning, (3) uses of technology, (4) duration, and (5) methods of evaluation. Most of the projects were developed and conducted by academic staff in universities, while the activities were hosted and/or conducted in educational and/or clinical facilities. Finally, clinical staff do not always have the same access to literature that is enjoyed by academic staff. In order for the projects in this supplement to be in reach all of those who may be interested, we considered it important for it to be open access. As such, our intentions align closely with the open-access model used in Advances in Simulation [12].

\section{Acknowledgements}

Not applicable

\section{About This Supplement}

This ar_cle has been published as part of Advances in Simula_on, Volume 4 Supplement 1, 2019: Title. The full contents of the supplement are available at https:/advancesinsimulation.biomedcentral.com/articles/supplements/ volume-4-supplement-1

\section{Authors' contributions}

Both authors were involved in all aspects of the work. Both authors read and approved the final manuscript.

\section{Funding}

The publication cost of this article was funded by the School of Allied Health Sciences Griffith University.

\section{Availability of data and materials}

No primary data was used for this article.

Ethics approval and consent to participate

Not applicable

\section{Consent for publication}

Not applicable.

\section{Competing interests}

Both NT and GG are employed in Griffith University. NT was the co-author on four of the articles in this issue and principal investigator on funding that supported the work on five of the articles. GG was the editor for this special issue.

\section{Author details}

${ }^{1}$ School of Allied Health Sciences, Griffith University, Gold Coast Campus, Gold Coast, Queensland 4222, Australia. ${ }^{2}$ School of Pharmacy, Griffith University, Gold Coast Campus, Gold Coast, Queensland 4222, Australia.

Published: 20 December 2019

\section{References}

1. Danish SH, Reza Z, Sohail AA. Case reports and their importance in medical literature. J Pak Med Assoc. 2017;67(3):451-3.

2. Davies P. What is evidence-based education? Brit J Educ Stud. 1999;47(2): $108-21$

3. Cheng A, Kessler D, Mackinnon R, Chang TP, Nadkarni VM, Hunt EA, et al. Reporting guidelines for health care simulation research: extensions to the CONSORT and STROBE statements. Adv Simul. 2016;1 (1):25.

4. James W. Varieties of religious experience: a study in human nature. New York: Longmans, Green, and Co; 1917.p15
5. Weller JM, Nestel D, Marshall SD, Brooks PM, Conn JJ. Simulation in clinical teaching and learning. Med J Aust. 2012;196(9):594.

6. Walker S, Nestel D. Interprofessional simulation in a student community clinic: insights from an educational framework and contact theory. Adv Simul (Lond). 2019;to be confirmed:to be confirmed.

7. Reeves N, Waite M, Tuttle N. Simulated patient contributions to enhancing exercise physiology student clinical assessment skills. Adv Simul (Lond). 2019:to be confirmed.

8. O'Shea M, Reeves N, Bialocerkowski A. An inter-professional, telehealth diabetes human-patient simulation with students from Nutrition and Dietetics and Exercise Physiology. Adv Simul (Lond). 2019:to be confirmed.

9. Edwards S, Tuttle N. Using stakeholder input to inform scenario content of simulated learning environments: an example case. Adv Simul (Lond). 2019: to be confirmed.

10. Tuttle N, Horan S. The effect of replacing one week of content teaching with an intensive simulation-based learning activity on physiotherapy student clinical placement performance. Adv Simul (Lond). 2019:to be confirmed.

11. Howells S, Cardell E, Waite M, Bialocerkowski A, Tuttle N. Augmentative and alternative communication skill development in speech-language pathology through telepractice simulation. Adv Simul (Lond). 2019:to be confirmed.

12. Nestel D. Open access publishing in health and social care simulation research. Adv Simul (Lond). 2016;1:2.

\section{Publisher's Note}

Springer Nature remains neutral with regard to jurisdictional claims in published maps and institutional affiliations.
Ready to submit your research? Choose BMC and benefit from:

- fast, convenient online submission

- thorough peer review by experienced researchers in your field

- rapid publication on acceptance

- support for research data, including large and complex data types

- gold Open Access which fosters wider collaboration and increased citations

- maximum visibility for your research: over $100 \mathrm{M}$ website views per year

At BMC, research is always in progress.

Learn more biomedcentral.com/submissions 